\title{
Oxidative Modification of Neurofilament-L by the Cytochrome $c$ and Hydrogen Peroxide System
}

\author{
Jung Hoon Kang \\ Deparment of Genetic Engineering. Cheongit Lniversity, Cheongin 360-764, Korea. E-mail: jhkangachuack \\ Recened September 7, 2006
}

\begin{abstract}
As neurofilament proteins are major cytoskeletal components of neuron. abnormality of neurofilament is proposed in brain with neurodegenerative disorders such as Parkinson's disease (PD). Since oxidative stress might play a critical role in altering normal brain proteins. we investigated the oxidative modification of neurofilament- $\mathrm{L}$ (NF-L) induced by the reaction of cy tochrome $c$ with $\mathrm{H}_{2} \mathrm{O}_{2}$. When NF-L was incubated with cytochrome $c$ and $\mathrm{H}_{2} \mathrm{O}_{2}$. the protein aggregation was increased in cytochrome $c$ and $\mathrm{H}_{2} \mathrm{O}_{2}$ concentrationsdependent manner. Radical scavengers. azide. formate and $\mathrm{N}$-acetyl cysteine, prevented the aggregation of NF$\mathrm{L}$ induced by the cy tochrome $\mathrm{c} / \mathrm{H}_{2} \mathrm{O}_{2}$ sy stem. The formations of carbonyl group and dityrosine were obtained in cytochrome $\mathrm{c} / \mathrm{H}_{2} \mathrm{O}_{2}$-mediated $\mathrm{NF}-\mathrm{L}$ aggregates. Iron specific chelator. desferoxamine prevented the cytochrome $c / \mathrm{H}_{2} \mathrm{O}_{2}$ system-mediated NF-L aggregation. These results suggest that the cytochrome $c / \mathrm{H}_{2} \mathrm{O}_{2}$ șistem may be related to abnormal aggregation of NF-L which may be involved in the pathogenesis of PD and related disorders.
\end{abstract}

Key Words : Neurofilament-L. Cytochrome $c$, Oxidative stress. Parkinson`s disease

\section{Introduction}

Many studies in Parkinson's disease (PD) have been shown that $\mathrm{PD}$ might be caused by protein aggregation due to aberrant protein folding or disturbed protein degradation. 1.2 Lewy bodies (LBs) are cytoplasmic inclusions that are present consistently and with greatest frequency in neurons of the substantia nigra and locus ceruleus of patients with PD. ${ }^{3}$ The significance of brainstem LB lies in their intimate relation to neurodegeneration and PD. Indeed. the association between nigral LB formation and $\mathrm{PD}$ is so strong that the identification of a small number of nigral LB in asyptomatic patients has been interpreted by some as preclinical $\mathrm{PD}^{4.5}$

Detailed immunohistochemical studies indicate that neurofilaments are major components of LB. Neurofilaments are composed of three subunits. identified as light (NF-L). medium (NF-M) and heay (NF-H). Neurofilaments are heteropolymers requiring NF-L together with NF-M or NF$\mathrm{H}$ for polymer formation. ${ }^{7}$ All three subunits have been identified in LBs. ${ }^{8}$ Neurofilaments are the most abundant neuron-specific intermediate filaments ${ }^{9}$ and represent a major component of the neuronal cytoskeleton. It has been reported that peroxynitrite may nitrate tyrosine residues of NF-L. thereby altering NF assembly and causing neurofilament accumulation in neurons. ${ }^{11}$ Since NF-L is more abundant than the other two subunits in neurons. NF-L are more susceptible to oxidative stress.

Cytochrome $c$ is known to have two well defined physiological functions: regulation of the electron transfer in mitochondria and mediation of apoptosis. ${ }^{\text {]l }}$ Because cytochrome $c$ has a specific function in transfer of electrons between complex III and complex IV. a dysfunction of this molecule may trigger production of reactive oxygen species (ROS) in mitochondria. which would deteriorate the intracellular oxidative stress condition. ${ }^{12}$ It has been reported that mitochondrial dysfunction may be involved in a pathogenesis of neurodegenerative disorders ${ }^{13}$ In addition, cytochrome $c$ catalyses peroxidase-like reactions in vitro. ${ }^{14}$ Protein radicals induced by the peroxidative reaction of cytochrome $c$ with $\mathrm{H}_{2} \mathrm{O}_{2}$ and other oxidants have been detected by ESR spintrapping technique ${ }^{15.16}$ Protein-derived radicals then can lead to oxidative damage of biological macromolecules.

In this study. we investigated whether the cytochrome $c$ and $\mathrm{H}_{2} \mathrm{O}_{2}$ system is involved in the modification of NF-L. The present results revealed that the aggregation of NF-L was induced by cytochrome $c$ and $\mathrm{H}_{2} \mathrm{O}_{2}$ is due to the oxidative damage resulting from free radicals generated by a combination of the peroxidase activity of cytochrome $c$ and the Fenton reaction of free iron released from oxidatively damaged cytochrome $c$.

\section{Materials and Methods}

Materials. Cytoclurome $c$, azide. formate. $\mathrm{N}$-acetyl-cysteine. desferoxamine (DFX), ethylene glycol-bis(2-amino ethyl ether)- $N_{1} N_{1} N^{\prime}, N^{\prime}$-tetraacetic acid (EGTA). dithiothreitol (DTT), sodium dodecyl sulfate (SDS). 2,4-dinitrophenyl hydrazine $(\mathrm{DNPH})$ and monoclonal anti-neurofilament 68 antibody (mouse) were purchased from Sigma Chemical Co. (St. Louis. MO. U.S.A.). Chelex 100 resin (sodium form) was obtained from Bio-Rad (Hercules. CA. U.S.A.)

Preparation of neurofilament-L. Protein expression and purification of NF-L were performed as previously described. ${ }^{17} \mathrm{~A}$ full-length cDNA clone of mouse NF-L in a pET-3d vector transfected into $E$. coli (BL21). Bacteria were grown in Luria broth supplemented with $1 \mathrm{mM}$ isopropyl $\beta$-Dthiogalactopyranoside beginuing at an $\mathrm{OD}_{6 \mathrm{ic}} \mathrm{nm}$ reading of 
0.8 . After a further $3 \mathrm{~h}$ at $37{ }^{\circ} \mathrm{C}$. bacterial cells were harvested by centrifugation $\left(4.000 \times g\right.$ for $10 \mathrm{~min}$ at $\left.4^{\circ} \mathrm{C}\right)$. resuspended in standard buffer $(50 \mathrm{mM}$ MES. $170 \mathrm{mM}$ $\mathrm{NaCl}, 1 \mathrm{mM}$ DDT. $\mathrm{pH}$ 6.25). The cells were disnupted with a French press at a pressure of 20.000 p.s.i. and centrifuged at $8.000 \mathrm{~g}$ for $15 \mathrm{~min}$ at $4^{\circ} \mathrm{C}$. The supernatant was incubated for $3 \mathrm{~h}$ at $37^{\circ} \mathrm{C}$ and then was centrifuged at $100,000 \times \mathrm{g}$ for $20 \mathrm{~min}$ at $25^{\circ} \mathrm{C}$. The pellets containing the aggregated NF-L proteins were washed twice with standard buffer before they were dissolved in urea buffer ( $25 \mathrm{mM} \mathrm{Na}$-phosphate. $\mathrm{pH} 7.5$. $6 \mathrm{M}$ urea. $1 \mathrm{mM}$ EGTA and $1 \mathrm{mM}$ DTT). The sample was loaded onto a DEAE-Sepharose column and was eluted with a linear $25-500 \mathrm{mM}$ phosphate gradient in urea buffer and 80 $\mathrm{ml} \mathrm{NF-L} \mathrm{eluted} \mathrm{between} 300$ and $360 \mathrm{mM}$ phosphate. These fractions were pooled and either used directly or stored at $-80^{\circ} \mathrm{C}$ for later experiments. Protein concentration was determined by the BCA method. ${ }^{18}$

Analysis of NF-L modification. Oxidative modification of NF-L was carried out by the incubation of NF-L $(0.25$ $\mathrm{mg} / \mathrm{mL}$ ) with $10 \mu \mathrm{M}$ cytochrome $c$ and $500 \mu \mathrm{M} \mathrm{H}_{\Sigma} \mathrm{O}_{2}$ in 10 $\mathrm{mM}$ phosphate buffer ( $\mathrm{pH} 7.4$ ) at $37^{\circ} \mathrm{C}$. After incubation of the reaction mixtures. the mixtures were stopped by freezing at $-80^{\circ} \mathrm{C}$. The samples were treated with a $4 \times$ concentrated sample buffer $(0.25 \mathrm{mM}$ Tris-HCl. $8 \%$ SDS. $40 \%$ glycerol. $20 \% \beta$-inercaptoethanol, $0.01 \%$ bromophenol blue) and heated in boiling water for $10 \mathrm{~min}$. An aliquot of each sample was subjected to SDS-polyacryl amide gel electrophoresis (PAGE) as described by Laemmli. ${ }^{19}$ using a $12 \%$ acrylamide slab gel. For inmmunoblotting. the proteins on the polyacrylamide gel were electrophoretically transferred to nitocellulose membrane which was. in turn. blocked in $5 \%$ nonfat milk in Tris-buffered saline (TBS: $20 \mathrm{mM}$ Tris. $0.2 \mathrm{M}$ $\mathrm{NaCl} . \mathrm{pH} 7.5$ ) containing $0.05 \%$ tween- 20 (TTBS). The membrane was incubated for $1 \mathrm{~h}$ at room temperature with mouse monoclonal anti-neurofilament 68 antibody (1:400) in TTBS. The membrane was washed by TBS and incubated again with peroxidase labeled secondary antibody. The protein bands were visualized using enhanced chemiluminescence kit (ECL: Perkin-Elmer).

Detection of protein carbonyl compound. The carbonyl content of proteins was determined by immunoblotting with anti-DNP antibody as described elsewhere ${ }^{35}$ Both native and oxidized protein were incubated with $20 \mathrm{mM}$ DNPH in $10 \%(\mathrm{v} / \mathrm{v})$ trifluoroacetic acid at room temperature for $1 \mathrm{~h}$. After incubation. a neutralization solution ( $2 \mathrm{M}$ Tris) was added at room temperature for $15 \mathrm{~min}$. After SDS-PAGE of the derivatized protein with $12 \%$ polyacrylamide gel. the proteins were transferred onto a nitrocellulose sheet and then probed with rabbit anti-DNP sera used a dilution of 1:1000. The detection method used alkaline phosphatase-labelled goat anti rabbit IgG with the colorimetric detection system (Bio-Rad).

Detection of $0, \mathbf{O}^{\prime}$-dityrosine. The reactions for the detection of $\mathrm{O} . \mathrm{O}^{\prime}$-dityrosine were carried with NF-L $(0.25$ $\mathrm{mg} / \mathrm{mL}$ ), $10 \mu \mathrm{M}$ cy tochrome $c$ and $500 \mu \mathrm{M} \mathrm{H}_{2} \mathrm{O}_{2}$ in a total volume of $300 \mu \mathrm{L}$. The samples were diluted with $2.7 \mathrm{~mL}$ of Chelex 100-treated water and transferred to a curette (3
$\mathrm{mL}$ ). The fluorescence emission spectrum of the sample was then monitored in the $340-500$ region (excitation. $325 \mathrm{~nm}$ ) using fluorescent spectrometer SMF 25 (Bio-Tek Instruments).

Replicates. Unless otherwise indicated. each result described in this paper is representative of at least three separate experiments

\section{Results}

We first investigated whether the cytochrome $c$ can induce the aggregation of NF-L. For this purpose. NF-L was incubated with various concentrations of cytochrome $c$ and $\mathrm{H}_{2} \mathrm{O}_{2}$ under the pH 7.4 ( $10 \mathrm{mM}$ phosphate buffer) conditions at $37^{\circ} \mathrm{C}$ for $2 \mathrm{~h}$. Immunoblotting analy sis showed that the intensity for the original protein was reduced and new high molecular weight material was visualized at the stacker/ separator gel interface (Fig. 1). The aggregation of NF-L became apparent at $1 \mu \mathrm{M}$ cytochrome $c$ and $0.1 \mathrm{mM} \mathrm{H}_{2} \mathrm{O}_{2}$ : the aggregation increased up to $30 \mu \mathrm{M}$ cytochrome $c$ and $\mathrm{l}$ $\mathrm{mM} \mathrm{H}_{2} \mathrm{O}_{2}$, respectively.

The effect of radical scavengers on the aggregation of NF$\mathrm{L}$ by the cytochrome $\mathrm{c} / \mathrm{H}_{2} \mathrm{O}_{2}$ sy stem was studied. The aggregation of NF-L by the cytochrome $c / \mathrm{H}_{2} \mathrm{O}_{2}$ system was significantly suppressed in the presence of azide. fonnate

(A)

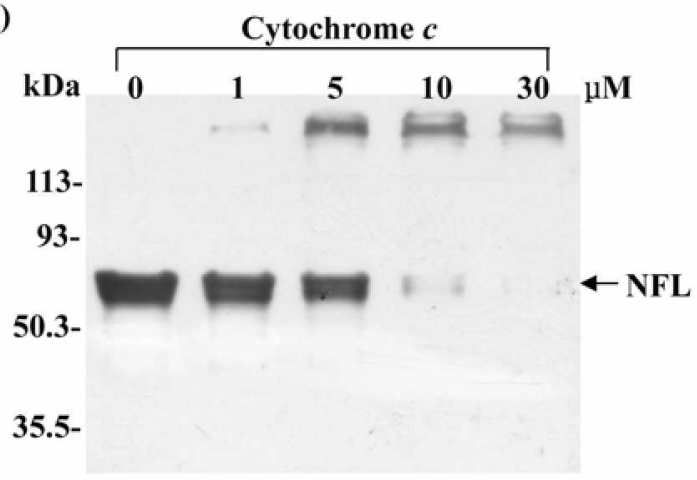

(B)

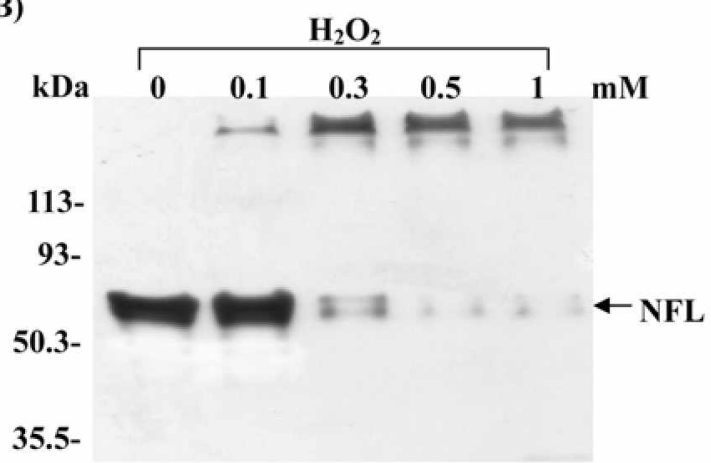

Figure 1. Aggregation of NF-L by the cytochrome $c$ and $\mathrm{H}_{2} \mathrm{O}_{2}$ system analyzed by immunoblotting. NF-L $(0.25 \mathrm{mg} / \mathrm{mL})$ was incubated with various concentrations of cytochrome $c$ and various concentrations of $\mathrm{H}_{2} \mathrm{O}_{2}$ in $10 \mathrm{mM}$ phosphate buffer (pH 7.4) at 37 " $C$ ' for $2 \mathrm{~h}$. (A) NF-L was incubated with indicated concentrations of cytochrome $c$ and $500, / / \mathrm{M} \mathrm{H}_{2} \mathrm{O}_{2}$. (B) NF-L was incubated with $10, i \mathrm{M}$ cytochrome $\mathrm{c}$ and indicated concentarions of $\mathrm{H}_{2} \mathrm{O}_{3}$. The positions of molecular weight markers $(\mathrm{kL}) \mathrm{a})$ are indicated on the lett. 


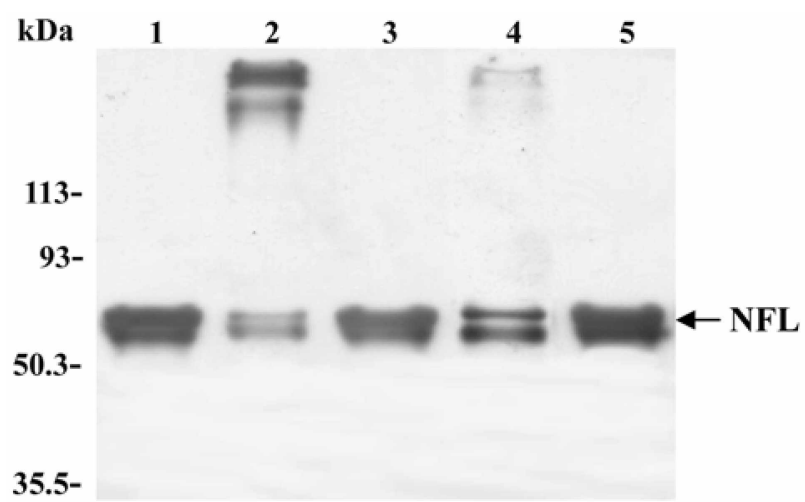

Figure 2. Eftect of radical scavengers on cytochrome $\mathrm{C} / \mathrm{H}_{2} \mathrm{O}_{2}$ system-mediated NF-I. aggregation. NF-I, (0.25 mg/ml) was incubated with $10 \mu \mathrm{M}$ cylochrome $c$ and $500 \mu \mathrm{M} \mathrm{II} \mathrm{O}_{2}$, in $10 \mathrm{mM}$ phosphate butfer (pH 7.4 ) at $37^{\circ} \mathrm{C}$ for $2 \mathrm{~h}$ in the presence of radical scavengers. Lane I. NF-L control; lane 2. no addition; lanc 3. 200 $\mathrm{mM}$ aride: lane 4. $200 \mathrm{mM}$ formale: lane 5. $10 \mathrm{mM} \mathrm{N}$-acetyl-L. cysteine.

and $\mathrm{N}$-acetyl-cysteine (Fig. 2). The result suggests that free radical might play a critical role in the aggregation of $\mathrm{NF}-\mathrm{L}$ by the cytochrome $c / \mathrm{H}_{2} \mathrm{O}_{2}$ system.

It has been shown that protein oxidation is accompanied the conversion of some amino acid residues into carbonyl derivatives..$^{20}$ The carbonyl content of protein can be measured using phenylhydrazine formation reaction. The method for detecting carbonyl-containing proteins employs derivatization with 2,4-DNPH followed by analysis with anti-DNP sera. Results obtained from the immunoblotting analysis of $\mathrm{NF}-\mathrm{L}$ aggregates are shown in Figure 3 . Carbonyl compounds were detected in the aggregates of $\mathrm{NF}-\mathrm{L}$ induced by the cytochrome $\mathrm{c} / \mathrm{H}_{2} \mathrm{O}_{2}$ system.

$\mathrm{O}, \mathrm{O}^{\prime}$-dityrosine crosslink formation between tyrosine resi-

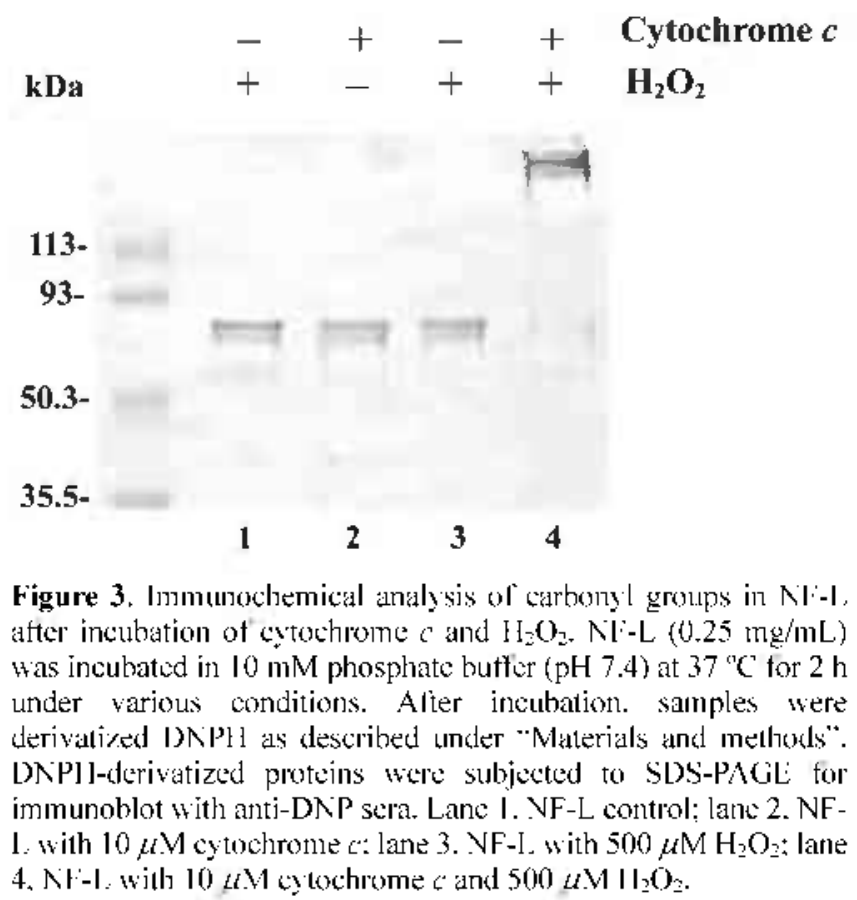

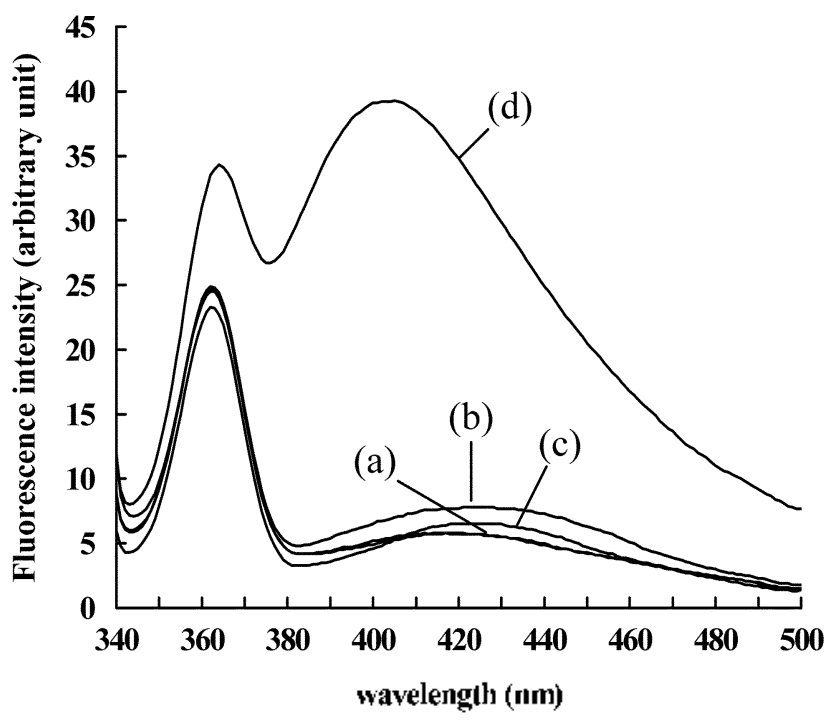

Figure 4. Fluorescence spectra of cytochrome $c / \mathrm{H}_{2} \mathrm{O}_{2}$ systemmedialed VII-I. aggregation. The flworescence specira of the formation of dityrosine was observed when NF-L $(0.25 \mathrm{mg} / \mathrm{mL})$ was incubated with or $w$ ithout $10 \mu \mathrm{M}$ cytochrome $c$ and $500 \mu \mathrm{M}$ $\mathrm{H}_{2} \mathrm{O}_{2}$ (a) NF-I control (b) NF-] + cylochrome c (c) NF-I. - $\mathrm{H}_{2} \mathrm{O}_{2}$ (d) $\mathrm{Nl}: \mathrm{I}, \mathrm{I}$ cytochrome $\mathrm{c}$ । $\mathrm{II}_{2} \mathrm{O}_{2}$.

dues may play a part in the formation of oxidative covalent protein crosslink. ${ }^{21}$ We investigated the formation of $\mathrm{O}, \mathrm{O}^{\prime}-$ dityrosine during the cytochrome $c \mathrm{H}_{2} \mathrm{O}_{2}$ system-mediated $\mathrm{NF}-\mathrm{L}$ aggregation by measuring fluorescence emission spectrum between 340 and $500 \mathrm{~nm}$ with an excitation at $325 \mathrm{~nm}$. The reactions were carried out with NF-L in the presence or absence of cytochrome $c$ and $\mathrm{H}_{2} \mathrm{O}_{2}$. As the reactions were proceeded, the emission peak at $410 \mathrm{~nm}$ due to the formation of $\mathrm{O}, \mathrm{O}^{\prime}$-dityrosine crosslinks was increased (Fig. 4).

Because iron ion could be released from the oxidatively damage cytochrome $c$ by $\mathrm{H}_{2} \mathrm{O}_{2}{ }^{2-}$ it was predicted that iron

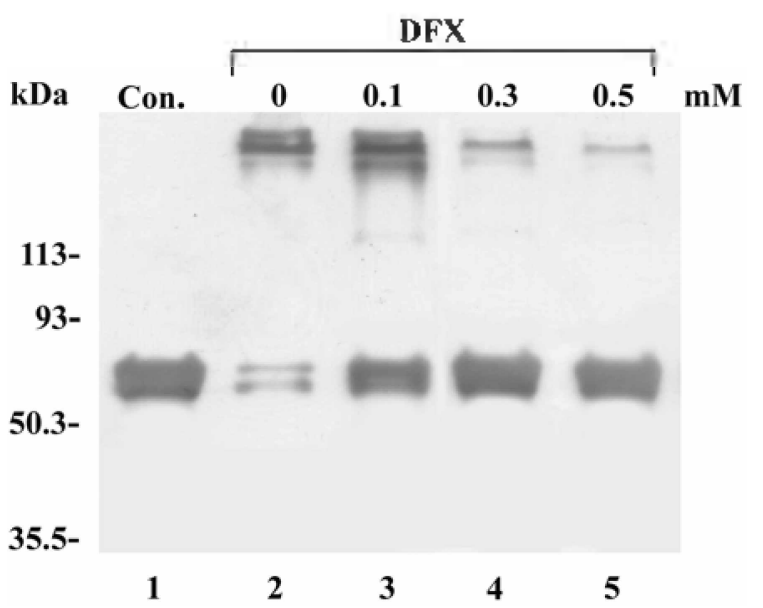

Figure 5. l:Hect of iron chetator on cylochrome dila $\mathrm{O}_{2}$ systemmediated NJ-L aggregation. Nli-L $(0.25 \mathrm{mg} / \mathrm{mL})$ was incubated with $10 \mu \mathrm{M}$ ey tochrome $c$ and $500 \mu \mathrm{M} \mathrm{H}_{2} \mathrm{O}_{3}$. in $10 \mathrm{mM}$ phosphate bulfer $(\mathrm{pH} 7.4)$ at $37 \times \mathrm{C}$ for $2 \mathrm{~h}$ in the presence of iron chelator. I.ane 1. NI-I. control; lane 2, no addition: lane 3. 0.1 m.M I) :X: lane $4.0 .3 \mathrm{mM}$ LIXX: lane $5.0 .5 \mathrm{mM} \mathrm{DIXX}$. The positions of molecular wight markers ( $k \mathrm{Da})$ are indicated on the left. 
may be contributed to the cytochrome $c_{2} / \mathrm{H}_{2} \mathrm{O}_{-}$-induced aggregation of NF-L. To test this possibility: we have investigated the effects of the iron chelators on the aggregation of NF-L by the cytochrome $c / \mathrm{H}_{2} \mathrm{O}_{2}$ system. The cy tochrome $c /$ $\mathrm{H}_{2} \mathrm{O}_{2}$-induced aggregation of NF-L was siguificantly inhibited by iron chelators. DFX (Fig. 5). These results suggest that iron ions are involved in the aggregation of NF-L by the cytochrome $\mathrm{c} / \mathrm{H}_{2} \mathrm{O}_{2}$ system.

\section{Discussion}

NF-L. a major structural protein inportant to the survival of neurons, was modified by the cytochrome $c / \mathrm{H}_{2} \mathrm{O}_{2}$ system. Neurofilaments are susceptible to oxidation in part because they are among the most abundant proteins in a cell. Previous studies have suggested that oxidative stress might play a critical role in the pathogenesis of $\mathrm{PD}$. Biochemical analysis of LB has shown them to be composed largely of a $68 \mathrm{kDa}$ protein that was soluble in formic acid a result that almost certainly precludes covalent crosslinking of protein. ${ }^{256}$ It has been reported that free radicals were generated in the reaction of cytochrome $c$ with $\mathrm{H}_{2} \mathrm{O}_{2}$, and that free radical formation was linear with respect to the concentrations of $\mathrm{cy}$ tochrome $\mathrm{c}$ and $\mathrm{H}_{2} \mathrm{O}_{-}{ }^{.}{ }^{37}$ Therefore. we suggest that free radicals formed by the cytochrome $c / \mathrm{H}_{2} \mathrm{O}_{2}$ may be involved in the aggregation of NF-L. Evidence that radical scavengers protected NF-L aggregation induced by the cy tochrome $c / \mathrm{H}_{2} \mathrm{O}_{2}$ (Fig. 2) supports this mechanism. Cytoclurome $c$ forms tyrosyl radicals when exposed to $\mathrm{H}_{2} \mathrm{O}_{2}$, and these radicals can be transferred to tyrosine residues on other protein. ${ }^{3 s}$ In this context. we hypothesize that tyrosines are key residues in the aggregation of neurofilament in the cytochrome $\mathrm{c} / \mathrm{H}_{2} \mathrm{O}_{2}$ system. The data in Figure 4 shows that the formations of dityrosine are detected in NF-L aggregates. Therefore. we suggest that tyrosines in NF-L are required for NF-L aggregation.

Trace metal such as iron and copper, which are variously present in biological systents. may interact with ROS, to danage macromolecules. ${ }^{2.52}$ The cleavage of the metalloproteins by oxidative damage may lead to increases in the levels of metal ions in some biological cell. ${ }^{3 \hat{3}}$ Previous reports showed that a metal chelator inhibited the peroxidase activity of cytochrome $c{ }^{27}$ The participation of iron ions in the cytoclurome $\mathrm{c} / \mathrm{H}_{2} \mathrm{O}_{-}-$mediated $\mathrm{NF}-\mathrm{L}$ aggregation was investigated by an examination of the protective effects of the iron chelator DFX. The results showed that DFX significantly prevented the aggregation of NF-L induced by the cytochrone $c / \mathrm{H}_{2} \mathrm{O}_{2}$ system (Fig. 5). It has been reported that iron ions released from the reaction of cytochrome $c$ with $\mathrm{H}_{2} \mathrm{O}_{2}$. This is likely due to the peroxidase activity of cy tochrome $c$. Interestingly. iron accunulation has been proposed a an inportant event in the nigral neurodegeneration of PD. ${ }^{34}$ Since iron ions could stimulate Fenton reaction to produce hydroxyl radical. NF-L aggregation may be mediated in the cytochrome $c / \mathrm{H}_{2} \mathrm{O}_{2}$ system via the generation of free radicals.
In conclusion, the results presented here suggest that cytochrome $c$, a well known electron transfer in mitochondria. may be involved in the stimulation of NF-L aggregation under pathological conditions.

\section{References}

1. Riess. O: Kuln. W: Krïger. R. J. Nemol. 2000. $2+7.69$.

2. Duda. T. E.: Giasson. B. I.: Chen1. Q.: Gur. T. L.: Gollomp. S. M.: Ischiropoulos. H.: Lee. V. M.-Y.: Trojanowski. J. Q. Am. J. Pathol. 2000. 157.1439.

3. Forno. L. S. Adv Newol 1986, 45.35

4. Gibb. W. R. G. Lees, A. J. J. Newol. Newo. Surg Psychiany 1988. 51,745

5. Gibb. W. R. G.: Lees. A. J. Netropathol Appl. Nenobiol 1989. 15. 27 .

6. Pollanen. M. S.: Dickson. D. W.: Bergeron. C. J. Neuropath. Exp. Neurol. 1993. 52, 183.

7. Lee. M. K.: Xu, Z:: Wong, P. C.; Cleveland, D. M. J. Cell. Biol. 1993. 122,1337 .

8. Hill. W. D.: Lee. V. M.-Y: Huritig. H. I.: Murray. T. M.: Trojanouski. J. Q. J. Conp. Neurol. 1991. 309.150.

9. Hoffimann. P. N.: Griffin. T. W.: Price. D. L. J. Cell. Biol 1984. 99. 705 .

10. Crow. J. P: Ye. Y. Z; Strong, M.: Kirk, M.: Barnes. S.; Beckman. J. S.J. Newochem. 1997.69. 1945.

11. Cai. T.: Tang. J.: Tones. D. P. Biochim. Biophns. Acta 1998. 1366. 139.

12. Shigenaga. M. K.: Hagen. T. M.: Ames. B. N. Proc. Natl. Acad. Sci. L.S.A. 1994. 91. 10771.

13. Schapira, A. H. I fov Disord 1994, 9. 125.

14. Vazquez-Duhalt, R. J. Hol. Catal. B Enzym. 1999. 7.241.

15. Barr. D. P.: Gunther. M. R.: Deterding. L. J.: Tomer. K. B.: Mason1. R. P. J. Biol. Chent 1996.271. 15498.

16. Chen. Y. R.; Deterding. L. J.: Sturgeon, B. E; Tomer, K. B.; Mason1. R. P. J. Biol. Chem. 2002. 277. 29781.

17. Kim. N. H.: Kang, J. H. J. Biochem Mol. Biol. 2003. 36. 488.

18. Smith. P. K: Krohn. R. I.: Hermanson, G. T: Mallia. A. K.; Gartner. F. H.: Provenzano. M. D.: Fujimoto, E. K.: Goeke. N. M.; Olson. B. T.: Klenk. D. C. Anal Bichem. 1985. 150.76.

19. Laemmli. U. K. Natme 1970. 227.680.

20. Levine. R. L.: Williams. J. A.: Stadtman. E. R.: Shacter. E. Nethods Enzymol 1994, 233, 346

21. Stadtman, E. R. Amm. Rev Biochem. 1993, 62.797.

22. Kim. N. H.: Jeong. M. S.; Choi. S. Y.: Kang, J. H. Mol. Cells 2006. 22.220.

23. Jenter. P.: Dalnow. C. W. Netmology 1996. $47 . \$ 161$

24. Jent1er. P. Hon: Disord 1998. 13. 24.

25. Pollanen, M. S.: Bergeron. C.: Weyer. L. d. Neurochem 1992. 58. 1953.

26. Pollanen, M. S.: Bergeron. C.: Weyer. L. Brain Res. 1993, 603. 121 .

27. Kim. N. H.: Jeong. M. S.: Choi. S. Y.: Knag. T. H. Bull. Korean Chent. Soc. 2004. 25. 1889.

28. Deterding, L. J.; Barr, D. P.; Mason. R. P.: Tomer. K. B. J. Biol. Chem. 1998. 273. 12863.

29. Goldstein. S.: Czapski. G. J. An Chent Soc. 1986. 108.2244

30. Sagripanti. J. L.: Swicord. M. L.: Davis. C. C. Radiat. Res. 1987. 110.219.

31. Inlay. T. A.: Chin. S. M.: Lint1. S. Science 1988. 240.640.

32. Sagripanti, L.; Kraemer. K. H. J. Biol. Chem. 1989, 264. 1729.

33. Kang. J. H.: Kim, S. M. Hol Cells 1997, 7. 553.

34. Youdim. M. B. H. Riederer. P. J. Nemal Transm. $1993,40$. 57.

35. Kang. J. H. Bull Korean Chem. Soc. 2006. 27.663. 